\title{
Phytotoxicity of imazapyr+imazapic on tolerant rice varieties Guri INTA CL and IRGA 424 RI $^{1}$
}

\author{
Maurício Limberger de Oliveira ${ }^{*} \mathbb{D}$, Enio Marchesan ${ }^{2}$, Camille Flores Soares ${ }^{2}$, Lucas Lopes Coelho ${ }^{2}$, \\ Isabel Schlegel Werle ${ }^{2}$ Alisson Guilherme Fleck ${ }^{2}$
}

10.1590/0034-737X201966020004

\begin{abstract}
Rice varieties from the Clearfield ${ }^{\circledR}$ system may present different tolerance levels to imidazolinone herbicides in function of application rate. The objective of this research was to evaluate the phytotoxicity of different rates of the formulated mixture of the herbicides imazapyr+imazapic applied on two tolerant irrigated rice varieties. The experiment was carried out in 2015/16 and 2016/17 growing seasons. A randomized complete block design was used in a factorial 2x6 with five replications. The factor A was composed by the tolerant rice varieties Guri INTA CL and IRGA 424 RI, and the factor $B$ by rates of the formulated mixture of the herbicides imazapyr+imazapic $\left(525+175 \mathrm{~g}\right.$ a.i. $\left.\mathrm{kg}^{-1}\right)$ of $0,140,210,280,350$,

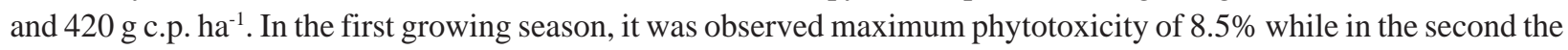
highest percentage was $13 \%$. The number of stems $\mathrm{m}^{-2}$, plant height, shoot dry matter, SPAD index, and grain yield were not influenced $(p<0.05)$ by herbicide rates. The application of the formulated mixture of the herbicides imazapyr+imazapic causes low initial phytotoxicity to the tolerant rice varieties Guri INTA CL and IRGA 424 RI up to three times the recommended rate, not influencing their grain yield.
\end{abstract}

Keywords: Clearfield ${ }^{\boxplus}$ system; imidazolinones; Oryza sativa.

\section{INTRODUCTION}

Facing the need of alternatives to control weedy rice (Oryza sativa), tolerant rice varieties to imidazolinone

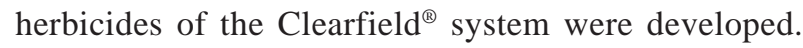
Herbicides belonging to this chemical group act on the inhibition of the acetolactate synthase enzyme (ALS), which acts on the synthesis of the branched chain amino acids valine, leucine, and isoleucine (Sudianto et al., 2013). Among the herbicides that are part of this group, it can be cited the formulated mixture of the molecules imazapyr and imazapic.

The plant tolerance mechanisms to imidazolinones are related to mutations where there is substitution of amino acids in the structure of the ALS enzyme, reducing sensitivity to these herbicides (Tan et al., 2005). In Brazil, the first imidazolinone-tolerant irrigated rice variety commercially licensed was IRGA 422 CL, developed from the lineage 93-AS3510, which in turn was produced by mutagenicity by the agent ethyl-metanesulfonate (Sudianto et al., 2013). Posteriorly, other rice varieties were developed, considered as second generation varieties as IRGA 424 RI and Guri INTA CL. In 2016/17 growing season, these varieties were responsible for $64.3 \%$ of the total rice field in the state of Rio Grande do Sul, Brazil, being that the first variety alone accounted for $43.9 \%$ (IRGA, 2017). Despite its considerable expressiveness on the rice productive chain in that state, the knowledge about the tolerance level of IRGA 424 RI to imidazolinone herbicides is limited due to its shorter usage time in relation to Guri INTA CL, which has been in the market for the longest time.

In irrigated rice, the responses to different herbicides of the imidazolinones chemical group, as well as to different rates, are dependent of the variety tolerance level, which

\footnotetext{
Submitted on September 25 th, 2018 and accepted on April 29th, 2019.

${ }_{11}^{1}$ This research is part of the first author's Master thesis.

${ }_{2}^{2}$ Universidade Federal de Santa Maria, Departamento de Fitotecnia, Santa Maria, Rio Grande do Sul, Brazil. mauriciodeoliveira8@hotmail.com; eniomarchesan@gmail.com; camilleflores@hotmail.com; lucas_1_c@ hotmail.com; isabelwerle@outlook.com; alissongfleck@gmail.com

* Corresponding author: mauriciodeoliveira8@ hotmail.com
}

Rev. Ceres, Viçosa, v. 66, n.2, p. 102-107, mar/abr, 2019 
may result in greater or less phytotoxicity to plants (Avila et al., 2005; Levy Junior et al., 2006). In function of the constant growth of resistant weeds as weedy rice, barnyard grass, and plants from cyperaceae family (Norsworthy $e t$ al., 2013), the increase in herbicide rates has been an increasingly common practice, which warns researchers and producers about the increase in phytotoxicity caused by imidazolinone herbicides in rice fields.

The utilization of high rates of herbicides from the imidazolinones chemical group in rice varieties with little known tolerance can result in damage to irrigated rice cultivation. Thus, the objective of this research was to evaluate the phytotoxicity of different rates of the formulated mixture of the herbicides imazapyr+imazapic applied on two tolerant irrigated rice varieties.

\section{MATHERIAL AND METHODS}

The experiment was carried out in the field during 2015/ 16 and 2016/17 growing seasons, in the municipality of Santa Maria, RS, Brazil ( $\left.29^{\circ} 43^{\prime} \mathrm{S} 53^{\circ} 43^{\prime} \mathrm{W}\right)$. The climate of the region is characterized, according to Köppen classification, as subtropical humid (Cfa) without dry season (Alvares et al., 2013). The soil of the experimental area is classified as Eutrophic Arenic Hexic Planosol, with the following chemical characteristics in the layer of 0 to $0.1 \mathrm{~m}$ : $\mathrm{pH}$ water $(1: 1)=5.8$; effective $\mathrm{CTC}=7.6 \mathrm{cmol}_{\mathrm{c}} \cdot \mathrm{dm}^{-3}$; base saturation $=63.7 \%$; saturation by $\mathrm{Al}=0$; organic matter $=2 \% ;$ clay $=25 \% ;$ P-Mehlich $=12.8 \mathrm{mg} \cdot \mathrm{dm}^{-3} ; \mathrm{K}=68$ mg. $\mathrm{dm}^{-3} ; \mathrm{Ca}=5.3 \mathrm{cmol}_{c} \cdot \mathrm{dm}^{-3} ; \mathrm{Mg}=2.2 \mathrm{cmol}_{c} \cdot \mathrm{dm}^{-3}$. The experimental design was a randomized block design, in a $2 \times 6$ factorial, with five replications. Factor A was composed by irrigated rice varieties Guri INTACL and IRGA424 RI, tolerant to herbicides from imidazolinones chemical group. Factor B was composed by different rates of the formulated mixture of the herbicides imazapyr+imazapic $\left(525+175 \mathrm{~g}\right.$ a.i. $\left.\mathrm{kg}^{-1}\right)$, which were $0,140,210,280,350$, and $420 \mathrm{~g}$ c.p. $\mathrm{a}^{-1}$. The 140 g c.p. ha ${ }^{-1}$ rate corresponds to the recommended rate to rice. The dimensions of the experimental units were $1.53 \mathrm{x}$ $8 \mathrm{~m}\left(12.24 \mathrm{~m}^{2}\right)$.

In the 2015/16 growing season, the herbicide application occurred only in post-emergence, in $\mathrm{V}_{3}$ stage (Counce $e t$ al., 2000), before irrigation establishment. In 2016/17 growing season, the application was split in two moments because of the lower precipitation during seeds germination in relation to the previous growing season, which allowed entry into the field. Thus, $50 \%$ of rate was applied in preemergence $\left(\mathrm{S}_{3}\right.$ stage) and the rest was applied in $\mathrm{V}_{3}$ stage. It was added to the spray mix the adjuvant Dash $\mathrm{HC}(0.5 \%$ v/v). A backpack sprayer pressurized by $\mathrm{CO}_{2}(275 \mathrm{kPa}$ pressure) was used coupled to a spray boom with four flat-type nozzles (Teejet XR110015 model), $0.50 \mathrm{~m}$ spaced, with an application rate of $125 \mathrm{~L} \mathrm{ha}^{-1}$.
In the 2015/16 growing season, planting was carried out on 10/21/2015, in a no-tillage system, in a field planted with soybeans in the previous growing season and ryegrass in the off-season. Ryegrass was desiccated with the herbicide glyphosate with a rate of $1500 \mathrm{~g}$ a.e. ha ${ }^{-1}, 60$ days before rice planting. The base fertilization used was $14 \mathrm{~kg} \mathrm{ha}^{-1}$ of N, $60 \mathrm{~kg} \mathrm{ha}^{-1}$ of $\mathrm{P}_{2} \mathrm{O}_{5}$, and $95 \mathrm{~kg}$ of K $\mathrm{K}_{2} \mathrm{O}$. Nitrogen top-dressing fertilization was $120 \mathrm{~kg} \mathrm{ha}^{-1}$, for both varieties, being the application split in $80 \mathrm{~kg} \mathrm{ha}^{-1}$ in $\mathrm{V}_{3}$ stage and 40 $\mathrm{kg} \mathrm{ha}^{-1}$ in $\mathrm{R}_{0}$ stage. Potassium top-dressing fertilization was $30 \mathrm{~kg} \mathrm{ha}^{-1}$ of $\mathrm{K}_{2} \mathrm{O}$ applied in $\mathrm{V}_{3}$ stage.

In the 2016/17, planting was carried out earlier in relation to the previous growing season, on 09/16/2017, in a minimum tillage system, with disking and soil planing, in a field previously planted with rice non-tolerant to imidazolinones and kept fallow during the off-season. Due to the lack of precipitation after planting, it was necessary an irrigation in order to stimulate plant emergence. Base fertilization was $20 \mathrm{~kg} \mathrm{ha}^{-1}$ of N, $80 \mathrm{~kg} \mathrm{ha}^{-1}$ of $\mathrm{P}_{2} \mathrm{O}_{5}$, and 80 $\mathrm{kg} \mathrm{ha}^{-1}$ of $\mathrm{K}_{2} \mathrm{O}$. Nitrogen top-dressing fertilization was 150 $\mathrm{kg} \mathrm{ha}^{-1}$, being applied $80 \mathrm{~kg} \mathrm{ha}^{-1}$ in $\mathrm{V}_{3}$ stage, $40 \mathrm{~kg} \mathrm{ha}^{-1}$ in $\mathrm{V}_{6}$ stage, and $30 \mathrm{~kg} \mathrm{ha}^{-1}$ in $\mathrm{R}_{0}$ stage. Potassium top-dressing fertilization was $40 \mathrm{~kg} \mathrm{ha}^{-1}$ applied in $\mathrm{V}_{3}$ stage. In both growing seasons, other cultural treatments were carried out according to crop technical recommendations for southern Brazil (Sosbai, 2014).

Soil temperature was monitored during initial period of rice cycle by sensors connected to a datalogger model HOBO U30, Onset brand, positioned in the 0-0.05 m layer of the soil. Air temperature and precipitation were obtained through the automatic meteorological station of $8^{\circ}$ Disme/ Inmet, 600 meters distant from the location of the experiment. Air and soil temperature, as well as precipitation data, are in Figure 1.

It was evaluated phytotoxicity in rice plants 7 and 14 days after herbicide application in $\mathrm{V}_{3}$ stage (DAA), attributing percentages based on leaf color, width, and growth, where zero represented absence of phytotoxicity and 100 plant death (Frans et al., 1986). At 7 and 21 DAA it was performed the counting of the number of stems in a $0.17 \mathrm{~m}^{2}$ area per experimental unit, being data posteriorly converted to stems $\mathrm{m}^{-2}$.

Plant height was obtained by the collection of 20 plants in sequence in the second planting row, also at 7 and 21 DAA, being measured from the first node of the stem base to the end of the last expanded leaf with a ruler. The same plants were oven dried at $65{ }^{\circ} \mathrm{C}$ for the determination of shoot dry matter. In the same days it was estimated chlorophyll content by SPAD index, in 10 plants per experimental unit, doing the measurements in lower, middle, and upper third of the last expanded leaf with a chlorophyll meter SPAD 502 DL model, Minolta brand. Rice harvest was performed when grains were 
presented mean humidity degree of $22 \%$, in a useful area of $4.08 \mathrm{~m}^{2}$ per experimental unit. After cleaning and weighing the grains, data were corrected to $13 \%$ of humidity and converted to $\mathrm{kg} \mathrm{ha}^{-1}$.

The analyzed variables were submitted to the test of the presuppositions of the mathematical model (normality of the errors and homogeneity of the variances). The variance analysis of experiment data and significance of qualitative factor means (rice varieties) was performed using the F test $(p<0.05)$. The means of the quantitative factor (herbicide rates), when significant, were submitted to polynomial regression analysis. For the phytotoxicity data the transformation $\sqrt{ }\left(\mathrm{y}_{0}+0.5\right)$ was used.

\section{RESULTS AND DISCUSSION}

In the 2015/16 growing season there was significance $(p<0.05)$ only to herbicide rates in the phytotoxicity evaluations. There was an increasing behavior in that percentage as herbicide rate increased (Figures $2 \mathrm{a}$ and $2 \mathrm{~b}$ ). At 7 DAA it was observed a maximum value of $7.5 \%$ in the highest applied rate, while at 14 DAA there was an increase of $1 \%$ for that same rate in relation to the previous evaluation. In the recommended rate $\left(140 \mathrm{~g} \mathrm{c}\right.$.p. ha $\left.{ }^{-1}\right)$, at 7 DAA, it was obtained a percentage of $1.5 \%$, and in the following evaluation no symptoms were observed.

In the 2016/17 growing season, besides the significance for herbicide rates, difference was also observed $(p<0.05)$ between rice varieties (Figures $2 \mathrm{e}$ and $2 \mathrm{f}$ ), however there was no interaction between factors. In the evaluations performed 7 and 14DAA, the variety IRGA 424 RI presented phytotoxicity percentage $50 \%$ higher in relation to the variety Guri INTACL. Levy Junior et al. (2006) found up to 78\% of phytotoxicity in the tolerant rice variety CL 121 in the $\mathrm{V}_{3}-\mathrm{V}_{4}$ stage, while in the variety CL 161 the maximum value obtained was $13 \%$, which evidences differences of tolerance between varieties. However, it is emphasized that in the present study the observed values were low, being $6.2 \%$ the maximum
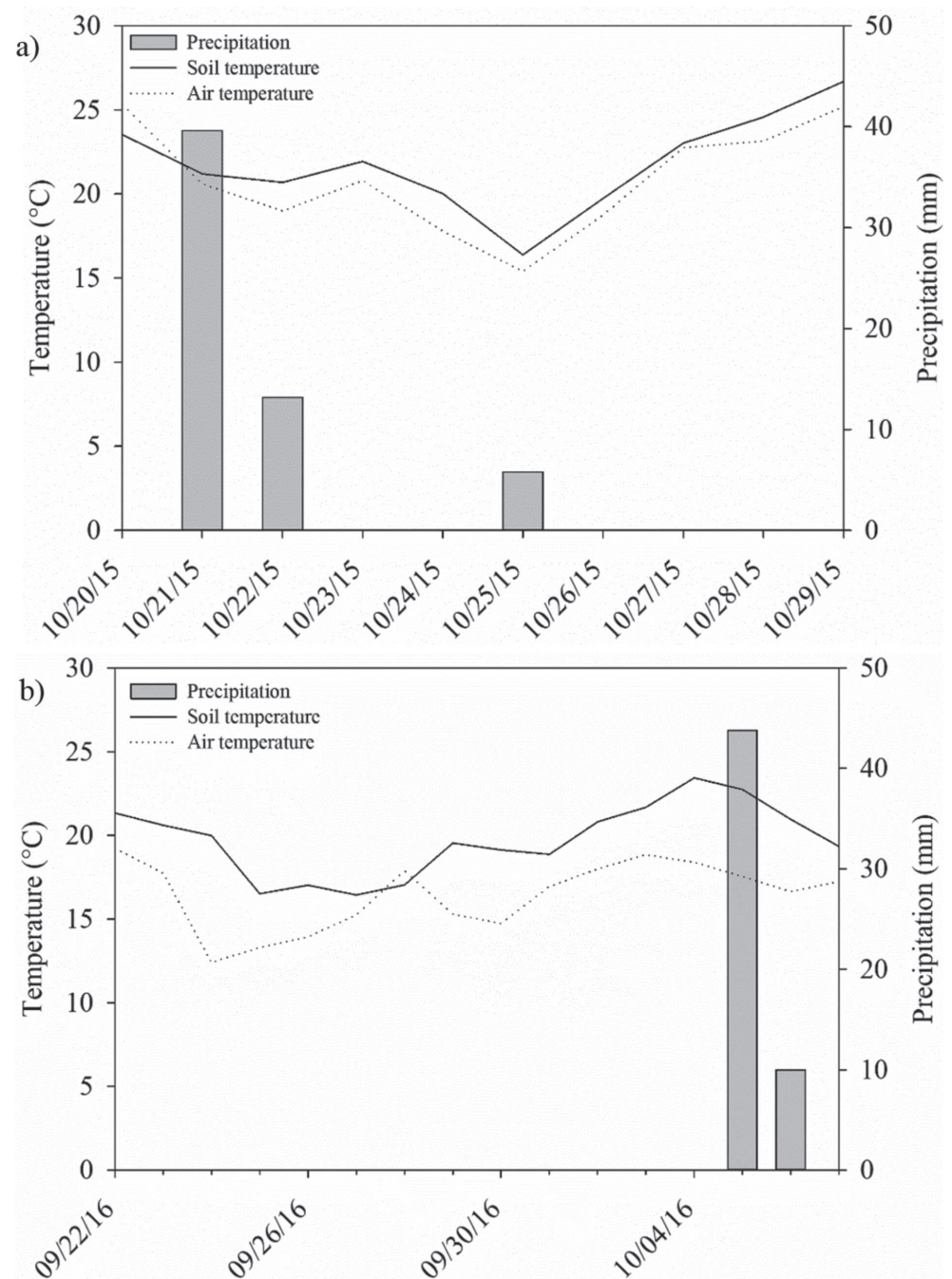

Figure 1: Mean daily soil temperature, in the 0-0.05 m layer, mean daily air temperature, and precipitation during the initial period of irrigated rice growing in the 2015/16 (a) and 2016/17 growing season (b). 
percentage obtained. To the herbicide rates factor, the behavior was similar to the previous growing season (Figures $2 \mathrm{c}$ and $2 \mathrm{~d}$ ), with maximum value of $13 \%$ for the $420 \mathrm{~g}$ c.p. $\mathrm{ha}^{-1}$ rate in both evaluations. These results corroborate with Marchesan et al. (2011) where there was observed phytotoxicity close to this value (17\%) in the tolerant variety IRGA $422 \mathrm{CL}$, with application in pre and post-emergence of the formulated mixture of the herbicides imazetha pyr + imazapic in the rate of $75+25 \mathrm{~g}$ a.i. ha- 1 .

In general, it was observed higher phytotoxicity in the second growing season. This fact may be explained in parts due to the lower soil and air temperature during initial period of rice growing (Figure 1), in function of the planting has been carried out earlier compared to the first growing season. Low temperatures reduce the cytochrome P450 monoxygenase activity in plants, which acts in the phase I of the metabolism of several herbicides, among them the ALS inhibitors (Siminszky, 2006).

However, it is important to highlight that in both growing seasons the phytotoxicity percentages found are considered low, slightly harmful and recoverable by the plants, being that 21 days after herbicide application it was not observed phytotoxicity of any applied rate on the two studied rice varieties. The number of stems $\mathrm{m}^{-2}$, plant height, shoot dry matter, SPAD index, and grain yield were not significantly influenced $(p<0.05)$ by
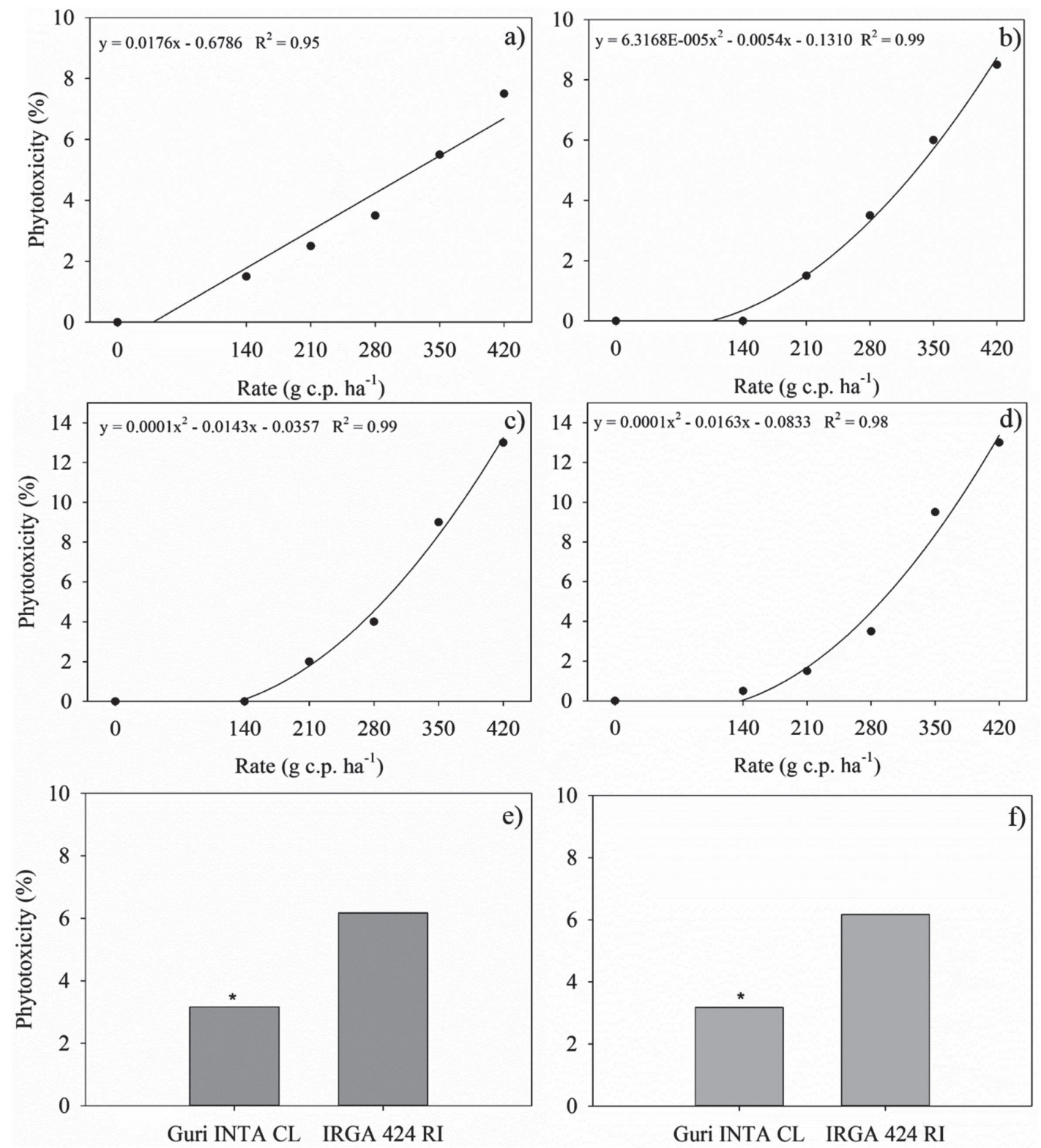

Figure 2: Phytotoxicity 7 (a) and 14 (b) days after application in the $\mathrm{V}_{3}$ stage (DAA) in the 2015/16 and 7 (c) and 14 (d) DAA in the 2016/17 growing season of different rates of the formulated mixture of the herbicides imazapyr+imazapic in tolerant rice, and phytotoxicity 7 (e) and 14 (f) DAA in two tolerant rice varieties in the 2016/17 growing season. "Means differ from each other by $\mathrm{F}$ test $(p<0.05)$. 
Table 1: Number of stems by square meter, plant height (PH), shoot dry matter (SDM), and SPAD index, 7 and 21 days after herbicide application in $\mathrm{V}_{3}$ stage (DAA), and grain yield (GY) of two imidazolinone-tolerant rice varieties, 2015/16 and 2016/17 growing seasons.

\begin{tabular}{|c|c|c|c|c|c|c|c|c|c|}
\hline \multicolumn{10}{|c|}{$2015 / 16$ growing season } \\
\hline \multirow{2}{*}{ Variety } & \multicolumn{2}{|c|}{ Stems $\mathbf{m}^{-2}$} & \multicolumn{2}{|c|}{ PH (cm) } & \multicolumn{2}{|c|}{ SDM $\left(g_{\text {plant }}{ }^{-1}\right)$} & \multicolumn{2}{|c|}{ SPAD index } & \multirow{2}{*}{ GY $\left(\mathbf{k g ~ h a}^{-1}\right)$} \\
\hline & 7 DAA & 21 DAA & 7 DAA & 21 DAA & 7 DAA & 21 DAA & 7 DAA & 21 DAA & \\
\hline Guri INTA CL & $488 *$ & $1049 *$ & $29,8^{*}$ & $45,5^{*}$ & 0,179 ns & $1,274^{*}$ & $33,2 *$ & $37,2 *$ & $9378 *$ \\
\hline IRGA 424 RI & 557 & 1365 & 26,2 & 36,5 & 0,174 & 1,06 & 31,6 & 35,6 & 10022 \\
\hline Mean & 523 & 1207 & 28 & 41 & 0,177 & 1,167 & 32,4 & 36,4 & 9705 \\
\hline $\mathrm{VC}(\%)$ & 21,6 & 15,7 & 5,4 & 6,9 & 16,7 & 23,3 & 3,7 & 3,7 & 8,2 \\
\hline \multicolumn{10}{|c|}{ 2016/17 growing season } \\
\hline Guri INTA CL & $264^{\mathrm{ns}}$ & $840 *$ & $24,1 *$ & $41,1^{*}$ & $0,094 *$ & $0,706^{*}$ & $31,9 *$ & $36,5^{*}$ & $11327^{\mathrm{ns}}$ \\
\hline IRGA 424 RI & 265 & 932 & 21 & 34,5 & 0,07 & 0,512 & 29,9 & 35,3 & 10978 \\
\hline Mean & 265 & 886 & 22,5 & 37,8 & 0,084 & 0,609 & 30,9 & 35,9 & 11153 \\
\hline $\mathrm{VC}(\%)$ & 21,2 & 15,1 & 6,6 & 4,1 & 20,4 & 23,7 & 2,6 & 5,5 & 10 \\
\hline
\end{tabular}

* Means differ from each other in the column by $\mathrm{F}$ test $(p<0.05)$. ${ }^{\text {ns }}$ Not significant by $\mathrm{F}$ test.

herbicide rates in both varieties in the two studied growing seasons (Table 1). In these evaluations, there was significant difference $(p<0.05)$ only between varieties, except for shoot dry matter 7 DAA in the first growing season and for number of stems $\mathrm{m}^{-2} 7 \mathrm{DAA}$ and grain yield in the next growing season.

Imidazolinone-tolerant rice varieties can have the ability to detoxify herbicide molecules of that chemical group and recover from injuries caused by their application, as long as the plants are in optimal conditions for their growth and development (Webster \& Masson, 2001). Therefore, the adequate crop management as top-dressing nitrogen fertilization in up to five days after herbicide application in post-emergence, as well as the establishment of irrigation in sequence contributes to the mitigation of the herbicide effects (Avila et al., 2009). In study of Sousa et al. (2014), it was observed that the photosynthetic apparatus of the rice variety Puitá INTACL was injured by the application of the commercial rates of the herbicides imazapyr+imazapic and imazethapyr+imazapic. However, 30 days after application no further damage to plant metabolism was observed.

Although not causing severe damage to the two tolerant rice varieties studied, it is important to emphasize that imidazolinone herbicides have high persistence in the soil, being that their sorption is higher in soils with low $\mathrm{pH}$ and high organic matter (Kraemer et al., 2009a). In this way, the utilization of high rates may hamper the growing of crops in succession and rotation with Clearfield ${ }^{\circledR}$ rice as ryegrass in the off-season and imidazolinones non-tolerant rice in the next growing season (Kraemer et al., 2009b; Bundt et al., 2015). Furthermore, this practice can lead to increased selection pressure, increasing the possibility of emergence of new resistant weeds. Thus, it is recommended that the rates recorded for the crop are used.

\section{ACKNOWLEDGMENTS}

The authors thank the Coordination of Superior Level Staff Improvement (CAPES) by the scholarship to the first author, to the National Council for Scientific and Technological Development (CNPq) by the financial support and by the research productive scholarship to the second author, and to the Research Support Foundation of the State of Rio Grande do Sul (FAPERGS) by the scholarship to the third author.

\section{CONCLUSION}

The application of the formulated mixture of the herbicides imazapyr+imazapic causes low initial phytotoxicity to the tolerant rice varieties Guri INTA CL and IRGA 424 RI up to three times the recommended rate, not influencing their grain yield.

\section{REFERENCES}

Alvares CA, Stape JL, Sentelhas PC, Gonçalves JLM \& Sparovek G (2013) Köppen's climate classification map for Brazil. Meteorologische Zeitschrift, 22:711-728.

Avila LA, Cezimbra DM, Marchesan E, Machado SLO, Pasini M, Glier C \& Ferreira RB (2009) Época de aplicação de nitrogênio e de início da irrigação na fitotoxicidade causada pela aplicação de imidazolinonas em arroz tolerante. Ciência Rural, 39:1647-1652.

Avila LA, Lee D, Senseman SA, Mccauley GN, Chandler JM \& Cothren JT (2005) Assessment of acetolactate synthase (ALS) tolerance to imazethapyr in red rice ecotypes (Oryza spp.) and imidazolinone tolerant/resistant rice (Oryza sativa) varieties. Pest Management Science, 06:171-178.

Bundt ADC, Avila LA, Agostinetto D, Nohatto MA \& Vargas HC (2015) Carryover of imazethapyr + imazapic on ryegrass and non-tolerant rice as affected by thickness of soil profile. Planta Daninha, 33:357-364.

Counce PA, Keisling TC \& Mitchell AJ (2000) A uniform, objective and adaptive system for expressing rice development. Crop Science, 40:436-443. 
Frans R, Talbert R, Marx D \& Crowley H (1986) Experimental design and techniques for measuring and analyzing plant responses to weed control practices. In: Camper ND (Ed.) Research methods in weed science. Las Cruces, USA Southern Weed Science Society. p.29-46.

IRGA - Instituto Rio Grandense do Arroz (2017) As 10 cultivares mais plantadas no Rio Grande do Sul - Safra 2016/17. Available in: <http://www.irga.rs.gov.br/upload/20170321160530cultivares_rs_2016_17.pdf>. Access: March 24, 2017.

Kraemer AF, Marchesan E, Avila LA, Machado SLO \& Grohs M (2009a) Destino ambiental dos herbicidas do grupo das imidazolinonas - revisão. Planta Daninha, 27:629-639.

Kraemer AF, Marchesan E, Avila LA, Machado SLO, Grohs M, Massoni PFS \& Sartori GMS (2009b) Persistência dos herbicidas imazethapyr e imazapic em solo de várzea sob diferentes sistemas de manejo. Planta Daninha, 27:581-588.

Levy Junior RJ, Bond JA, Webster EP, Griffin JL, Zhang WP \& Linscombe SD (2006) Imidazolinone-tolerant rice response to imazethapyr application. Weed Technology, 20:389-393.

Marchesan E, Massoni PFS, Villa SCC, Grohs M, Avila LA, Sartori GMS \& Ferreira RB (2011) Produtividade, fitotoxicidade e controle de arroz-vermelho na sucessão de cultivo de arroz irrigado no Sistema CLEARFIELD ${ }^{\circledR}$. Ciência Rural, 41:17-24.
Norsworthy JK, Bond J \& Scott RC (2013) Weed management practices and needs in Arkansas and Mississippi rice. Weed Technology, 27:623-630.

Sosbai - Sociedade Sul-Brasileira de Arroz Irrigado (2014) Arroz Irrigado: recomendações técnicas da pesquisa para o sul do Brasil. Santa Maria, Sociedade Sul-Brasileira de Arroz Irrigado. 189p.

Siminszky B (2006) Plant cytochrome P450-mediated herbicide metabolism. Phytochemistry Reviews, 05:445-458.

Sousa CP, Pinto JJO, Martinazzo EG, Perboni AT, Farias ME \& Bacarin MA (2014) Chlorophyll a fluorescence in rice plants exposed of herbicides of group imidazolinone. Planta Daninha, 32:141-150.

Sudianto E, Beng-Kah S, Ting-Xiang N, Saldain NE, Scott RC \& Burgos NR (2013) Clearfield ${ }^{\circledR}$ rice: Its development, success, and key challenges on a global perspective. Crop Protection, 49:40-51.

Tan S, Evans RR, Dahmer ML, Singh BK \& Shaner DL (2005) Imidazolinone-tolerant crops: history, current status and future. Pest Management Science, 61:246-257.

Webster EP \& Masson JA (2001) Acetolactate synthase-inhibiting herbicides on imidazolinone-tolerant rice. Weed Science, 49:652-657. 